\title{
Wood-Based Compost Affects Soil Fertility and the Content of Available Forms of Nutrients in Vineyard and Field-Scale Agroecosystems
}

\author{
Diego Pizzeghello $\left.{ }^{1, *} \mathbb{(}\right)$, Livio Bellin ${ }^{1}\left(\mathbb{D}\right.$, Serenella Nardi ${ }^{1}\left(\mathbb{D}\right.$, Ornella Francioso ${ }^{2}\left(\mathbb{D}\right.$, Andrea Squartini ${ }^{1}(\mathbb{D}$ \\ and Giuseppe Concheri ${ }^{1}$ (D) \\ 1 Department of Agronomy, Food, Natural Resources, Animals and Environment (DAFNAE), \\ Padova University, 35020 Legnaro, Italy; liviobellin@gmail.com (L.B.); serenella.nardi@unipd.it (S.N.); \\ squart@unipd.it (A.S.); giuseppe.concheri@unipd.it (G.C.) \\ 2 Department of Agricultural and Food Sciences, Bologna University, 40127 Bologna, Italy; \\ ornella.francioso@unibo.it \\ * Correspondence: diego.pizzeghello@unipd.it; Tel.: +39-49-8272845
}

\section{check for} updates

Citation: Pizzeghello, D.; Bellin, L.; Nardi, S.; Francioso, O.; Squartini, A.; Concheri, G. Wood-Based Compost Affects Soil Fertility and the Content of Available Forms of Nutrients in Vineyard and Field-Scale Agroecosystems. Agronomy 2021, 11, 518. https://doi.org/10.3390/ agronomy11030518

Academic Editor:

Francesco Montemurro

Received: 15 February 2021

Accepted: 7 March 2021

Published: 10 March 2021

Publisher's Note: MDPI stays neutra with regard to jurisdictional claims in published maps and institutional affiliations.

Copyright: (c) 2021 by the authors Licensee MDPI, Basel, Switzerland. This article is an open access article distributed under the terms and conditions of the Creative Commons Attribution (CC BY) license (https:// creativecommons.org/licenses/by/ $4.0 /)$.

\begin{abstract}
To counteract the loss of organic matter of agricultural soils, the use of compost from green and woody residues is a promising strategy. In this study, an organic farm (NE Italy) was investigated to determine the effect of management practices on physical and chemical soil properties. The organic system received three years ago a single high dose $\left(60 \mathrm{t} \mathrm{ha}^{-1}\right)$ of a wood-based compost (WBC), and it was compared with a conventional farm that annually managed mineral plus manure fertilization. In both systems, soil samples from a vineyard and field-scale rotation were collected, together with soil samples from an area not cultivated and not treated neither with compost nor with fertilizers or manure (untreated $=$ control). Soil samples were characterized for soil fertility parameters, extractable fractions of macro- and micronutrients with DTPA and Mehlich3, and their total content. WBC was physically, chemically, and biologically characterized. The results showed that WBC fulfilled the requirements prescribed by Italian legislation, and the absence of phytotoxicity and conversely a stimulating activity towards root development was evidenced. From the DNA metabarcoding of the bacterial community, WBC revealed several peculiarities, including the dominance of taxa such as the order Acidimicrobiales, the families Anerolineaceae, Cytophagaceae, Caldimicrobiacese, Saprospiraceae and the archaeon Candidatus Nitrososphaera. Concerning the fertility of soils, the addition of WBC in both the vineyard and field-scale considerably affected some important soil parameters compared to those of conventional fertilization and untreated soil. Among these, WBC strongly increased the organic C content and the amount of the available P. In addition, the concentrations of macro- and micronutrients extractable by DTPA were generally higher with WBC than conventional fertilization. On the contrary, Mehlich3 extractable metals and total metals content were not affected by fertilization. The principal component analysis indicated that organic $\mathrm{C}$, macronutrients (Ca $\mathrm{DTPA}_{\mathrm{DT}}, \mathrm{K}_{\mathrm{DTPA}}$, and POlsen), as well as micronutrients ( $\mathrm{B}_{\mathrm{DTPA}}, \mathrm{Fe}_{\mathrm{DTPA}}$, and Mo $\mathrm{DTPA}_{\mathrm{D}}$ ) are principal factors that properly separated conventional fertilization from organic fertilization. Beside this, within the same management, cases by agroecosystem were also well revealed by cluster analysis. In essence, in the short-term, the organic system led to a significant improvement in organic $\mathrm{C}$ and plant-available nutrients over the conventional system.
\end{abstract}

Keywords: soil organic carbon; soil fertility; organic farm; DTPA; bacterial community; woodbased compost

\section{Introduction}

It is known that at the global scale, especially in the Mediterranean region, there is a serious loss of organic matter in agricultural soils. The reducing of organic matter has a 
direct negative effect on soil fertility, leading to increased demand for medium and longterm energy and economic needs (i.e., fertilizers, irrigation, disease control), and a gradual decline in productivity [1]. Over time, the decline of soil quality has led to the irreversibility of this process, and the incidence of erosion and desertification has increased [2]. Therefore, there is an urgent need for agronomic practices that can reduce carbon loss and even increase soil carbon storage. This includes improving crop varieties, expanding crop rotations, avoiding, or reducing the use of bare fallow, and applying organic fertilizers such as compost or waste products from animal husbandry [3,4]. Although these practices are not common in conventional agriculture, they are core practices of organic agriculture where crop production relies in large part on closed nutrient cycles by returning plant residues and manures back to the land. Organic agriculture is an ecological production management system that can promote and enhance biodiversity, biological cycles, and soil biological activities. It is based on the minimal use of off-farm inputs and on management practices that restore, maintain, and enhance ecological harmony. By contrast, conventional agricultural systems are characterized by high inputs of organic and mineral fertilizers, pesticides, and fossil fuel use, as well as heavy dependence on external sources and large capital investments. Therefore, it is assumed that the adoption of organic agriculture will lead to a reduction in soil carbon loss and even higher soil carbon concentrations and net carbon sequestration over time [5]. Although some evidence supports that the carbon content in organically managed soil is higher than that in integrated or conventionally managed soil [6,7], other studies have not found this difference [8,9]. As a result of these contrasting results, the advantages and disadvantages of organic farming systems versus conventional management are a matter of active debate.

In recent years, organic agricultural production has developed rapidly due to its potential to be regarded as healthy food and consumer benefits, as well as EU agricultural policies. According to data from the Research Institute of Organic Agriculture, in 2015, there were 179 diverse organic producing countries in the world, with a total of 50.9 million hectares of farmland dedicated to organic production, which is approximately the total area of Spain. Studies comparing soils of organically and conventionally managed farming systems have documented higher soil organic matter and total $\mathrm{N}$ with the use of organic practices [10]. Notably, the increases in soil organic matter following the transition to organic management occur slowly, and it usually takes several years do detect them [11], but they can have a huge impact on long-term productivity. It has been found that changes in other soil properties are more variable, which may be due to differences in climate, crop rotation, soil type, or the length of time the soil is under organic management. Generally, under organic production, soil $\mathrm{pH}$ is higher, and the nutrients available to plants, especially K, may be higher. Since these soil properties are critical to determining the fertility of agricultural soils, the ability to predict and manage the dynamics and temporal and spatial intensity of soil properties will facilitate the transition to organic farming systems.

In such a context, various composting materials have been proposed as candidates for improving soil fertility, including municipal solid waste, sewage sludge, animal manure, and agro-industrial waste [12]. Among the possible composting materials, those based on green and woody refuse may be the most promising [13-15]. In cities in developed countries, the annual output of green residues (pruning, leaves, and wood chips) exceeds 20,000 tons per year, and green residues account for $30 \%$ of the total weight of municipal solid waste [16]. Green compost has been tested in several experiments for vegetable cultivation [17], shrubs [18], and ornamental plants [15]. The standardization of compost characteristics is regarded as one of the main problems in its actual use. Choosing locally produced composting materials is one way to obtain high-quality and standard green compost, which is not possible for many other compost types (for example, compost from municipal organic waste) [19]. Therefore, lignocellulosic residues from the farms are recognized as an excellent supply of organic matter that contributes to better soil C-stock, as well as nutrient recycling according to the principles of circular economy. 
The purpose of this work is to study the effects of wood-based compost distributed on an organically managed farm in a vineyard and field-scale crop rotation. The effect of the improvement of soil fertility parameters, especially organic matter, nutrients content and availability are investigated. The results were compared with those obtained using mineral plus manure fertilization on a neighboring conventional farm and untreated (control) soil. The effect of organic amendment and conventional fertilizers on various heavy metals in the soil systems were also evaluated. The findings of this study are relevant for the use of wood-based compost in organically low-intensity land use.

\section{Materials and Methods}

\subsection{Study Area}

The study was conducted in the Berici hills, a group of reliefs of modest extension $\left(165 \mathrm{~km}^{2}\right)$ located in the province of Vicenza (NE Italy, $45^{\circ} 23^{\prime} \mathrm{N} ; 11^{\circ} 26^{\prime} \mathrm{E}$ ). The hills are a carbonate sedimentary formation of the Paleocene-Eeocene with a homogeneous and slightly arched profile, not particularly high above sea level; the highest summit is Monte Alto $(444 \mathrm{~m})$. The climate is characterized by an average annual temperature of $12{ }^{\circ} \mathrm{C}$ and an average annual precipitation of $900 \mathrm{~mm}$ with scarce distribution in winter and abundant in spring and autumn. In the flat or moderately steep karst areas there are thin soils such as Chromi-Epileptic Cambisols and Calcari-Rendzic Leptosols [20] and deeper soils such as Cutani-Chromic Luvisols and Chromic Cambisols [20]. In the reliefs on mainly terrigenous marine rocks, there are moderately deep soils such as Calcari-Endoleptic Cambisols and Calcari-Rendzic Leptosols [20], while on the steeper slopes Gleyic Calcisols and Eutric Cambisols [20]. The flora is thermophilic, of a warm climate environment, which is combined with micro-thermal vegetation typical of higher altitudes. The area is suited to viticulture.

\subsection{Experimental Setup}

Two farms, one organically and one conventionally managed, were chosen among a preliminary group on the basis of similarity in extension, morphology, and crop. The organic farm (Agrilux, Vicenza, Italy) covers an area of 44 ha and uses as amendment a wood-based compost (WBC) (Organic Forest ${ }^{\circledR}$, SORIFAV, Vicenza, Italy) derived from pruning woody residues (2/3) and lawn and leaf lipping (1/3). The main physical, chemical, and biological characteristics of the compost are reported in Table 1 . Here, it suffices to report that none of the analyzed parameters exceeded Italian regulations [21]. The organic farm did not receive any chemical fertilizer or pesticide. The organic farm has been certified with ICEA since 2014 and has been accredited with SIQURIA since 2016. The organic farm scheduled different agroecosystems of which two were considered: vineyard and field-scale crops, afterwards named OV and OFS. The vineyard is $90 \%$ Cabernet Sauvignon and $10 \%$ Merlot varieties and covers an area of 1.1 ha. The vines are an average of 20 years old and are planted with a density of 4500 per hectare. The field-scale is a plot of $2700 \mathrm{~m}^{2}$ of surface and is exclusively cultivated with a variable rotation with horticultural crops (i.e., potato, cabbage, peas, green beans, spelled, and tomato). The soil undergoes minimal processing by means of a subsoiler and subsequent milling of a layer not exceeding $30 \mathrm{~cm}$ in depth. Irrigation takes place with a drip system. A neighboring conventionally managed farm (35 ha) was selected under the same soil type and similar cropping agroecosystems with vineyard and field-scale crops named CV and CFS, respectively. 
Table 1. Physical, chemical, and biological characteristics of the wood-based compost (mean \pm SE).

\begin{tabular}{|c|c|c|c|}
\hline Parameter & Unit & Value & Limit \\
\hline Moisture * & $\mathrm{g} \mathrm{kg}^{-1} \mathrm{DM}$ & $444 \pm 11$ & $\leq 500$ \\
\hline Reaction * & $\mathrm{pH}$ & $6.7 \pm 0.1$ & $\overline{6}-8.5$ \\
\hline Electric conductibility (EC) & $\mathrm{mS} \mathrm{cm}^{-1}$ & $0.89 \pm 0.04$ & \\
\hline Salinity $* * *$ & meq $100 \mathrm{~g}^{-1} \mathrm{DM}$ & $5.09 \pm 0.5$ & \\
\hline Organic carbon $(\mathrm{OC}) *$ & $\mathrm{~g} \mathrm{~kg}^{-1} \mathrm{DM}$ & $340 \pm 31$ & $\geq 200$ \\
\hline Carbonates & $\mathrm{g} \mathrm{kg}^{-1} \mathrm{DM}$ & $143 \pm 12$ & \\
\hline Total nitrogen $(\mathrm{TN})^{* * *}$ & $\mathrm{~g} \mathrm{~kg}^{-1} \mathrm{DM}$ & $31 \pm 0.5$ & \\
\hline Organic $N^{*}$ & $\% \mathrm{TN}$ & $98 \pm 2.0$ & $>80$ \\
\hline C:N & & 10.96 & $\leq 50 *$ \\
\hline Humic carbon (HC) & $\mathrm{g} \mathrm{kg}^{-1} \mathrm{DM}$ & $180 \pm 3.6$ & $>25 *$ \\
\hline HA:FA & & 6.5 & \\
\hline Phosphorous $(\mathrm{P})^{* * *}$ & $\mathrm{mg} \mathrm{kg}^{-1} \mathrm{DM}$ & $3100 \pm 55$ & \\
\hline Potassium $(\mathrm{K}) * * *$ & $\mathrm{mg} \mathrm{kg}^{-1} \mathrm{DM}$ & $13,000 \pm 100$ & \\
\hline Calcium (Ca) & $\mathrm{mg} \mathrm{kg}^{-1} \mathrm{DM}$ & $26,700 \pm 1400$ & \\
\hline Magnesium (Mg) & $\mathrm{mg} \mathrm{kg}^{-1} \mathrm{DM}$ & $9800 \pm 300$ & \\
\hline Sulfur (S) & $\mathrm{mg} \mathrm{kg}^{-1} \mathrm{DM}$ & $4600 \pm 100$ & \\
\hline Iron $(\mathrm{Fe})$ & $\mathrm{mg} \mathrm{kg}^{-1} \mathrm{DM}$ & $13,370 \pm 1250$ & \\
\hline Sodium $(\mathrm{Na})^{* *}$ & $\mathrm{mg} \mathrm{kg}^{-1} \mathrm{DM}$ & $3600 \pm 100$ & \\
\hline Cupper $(\mathrm{Cu}) *$ & $\mathrm{mg} \mathrm{kg}^{-1} \mathrm{DM}$ & $45 \pm 2$ & $\leq 230$ \\
\hline $\operatorname{Zinc}(\mathrm{Zn}) *$ & $\mathrm{mg} \mathrm{kg}^{-1} \mathrm{DM}$ & $104.5 \pm 7.5$ & $\leq 500$ \\
\hline Boron (B) & $\mathrm{mg} \mathrm{kg}^{-1} \mathrm{DM}$ & $54.1 \pm 2.3$ & \\
\hline Manganese (Mn) & $\mathrm{mg} \mathrm{kg}^{-1} \mathrm{DM}$ & $832 \pm 10$ & \\
\hline Molybdenum (Mo) & $\mathrm{mg} \mathrm{kg}^{-1} \mathrm{DM}$ & $1.71 \pm 0.11$ & $<2+$ \\
\hline Cadmium $(\mathrm{Cd}) *$ & $\mathrm{mg} \mathrm{kg}^{-1} \mathrm{DM}$ & $0.80 \pm 0.01$ & $\leq 1.5$ \\
\hline Chromium & $\mathrm{mg} \mathrm{kg}^{-1} \mathrm{DM}$ & 13 & \\
\hline Chromium VI+ * & $\mathrm{mg} \mathrm{kg}^{-1} \mathrm{DM}$ & $0.053 \pm 0.03$ & $\leq 0.5$ \\
\hline Nichel $(\mathrm{Ni}) *$ & $\mathrm{mg} \mathrm{kg}^{-1} \mathrm{DM}$ & $5.8 \pm 0.7$ & $\leq 100$ \\
\hline Lead $(\mathrm{Pb})$ * & $\mathrm{mg} \mathrm{kg}^{-1} \mathrm{DM}$ & $12 \pm 0.3$ & $\leq 140$ \\
\hline Cobalt (Co) & $\mathrm{mg} \mathrm{kg}^{-1} \mathrm{DM}$ & $4.82 \pm 0.10$ & \\
\hline Salmonella & Mpn & Absent & Absent \\
\hline Escherichia coli & $\mathrm{UFC} g-1$ & Absent & $<1000$ \\
\hline Germination index $(\mathrm{GI})$ * & $\%$ & 130 & $>60$ \\
\hline Plastic glass materials* & $\mathrm{g} \mathrm{kg}^{-1} \mathrm{DM}$ & 0.1 Absent & $<5$ \\
\hline Inert lithoids * & $\mathrm{g} \mathrm{kg}^{-1} \mathrm{DM}$ & 0.1 & $<50$ \\
\hline
\end{tabular}

* To be respected; ${ }^{* *}$ to declare; *** declarable; + urban waste-based amendments.

Fertilization treatments considered for this study were as follows: (i) wood-based compost (WBC) at the rate of $60 \mathrm{tha}^{-1}$ in a single solution in 2015 in the organic vineyard and field-scale (OV, OFS); (ii) mineral fertilizer of $100 \mathrm{~kg} \mathrm{ha}^{-1} \mathrm{y}^{-1}\left(\mathrm{NH}_{4}\right)_{2} \mathrm{SO}_{4}-100 \mathrm{~kg} \mathrm{ha}^{-1}$ $\mathrm{y}^{-1} \mathrm{~K}_{2} \mathrm{SO}_{4}$-plus manure $1 \mathrm{tha}^{-1} \mathrm{y}^{-1}$ in the conventionally managed vineyard and fieldscale (CV, CFS); (iii) control (UNT) from an unfertilized and uncultivated area. The soil of control was a loamy clay with no skeleton, calcareous, subalkaline, endowed of moderate fertility with moderate organic $C$, and from low to moderate macro e micronutrient content (Table 2). 
Table 2. Physical and chemical characteristics of the soil top layer of the vineyards amended with the wood-based compost (OV), conventionally fertilized (CV), and untreated soil. Values represent the average of 10 replicates (main \pm standard deviation).

\begin{tabular}{|c|c|c|c|c|}
\hline \multirow{2}{*}{ Parameter } & \multicolumn{2}{|c|}{ Vineyard } & \multirow{2}{*}{ Untreated } & \multirow{2}{*}{ Anova } \\
\hline & Organic & Conventional & & \\
\hline $\mathrm{pH}$ & $8.0 \pm 0.1$ & $7.7 \pm 0.1$ & $7.7 \pm 0.2$ & n.s. \\
\hline $\mathrm{EC}\left(\mathrm{mS} \mathrm{cm}^{-1}\right)$ & $0.6 \pm 0.1 \mathrm{a}$ & $0.4 \pm 0.1 \mathrm{~b}$ & $0.2 \pm 0.1 \mathrm{c}$ & $*$ \\
\hline Sand $\left(\mathrm{g} \mathrm{kg}^{-1}\right)$ & $352 \pm 67$ & $304 \pm 68$ & $280 \pm 52$ & n.s. \\
\hline Silt $\left(\mathrm{g} \mathrm{kg}^{-1}\right)$ & $160 \pm 14$ & $188 \pm 10$ & $206 \pm 11$ & n.s. \\
\hline Clay $\left(\mathrm{g} \mathrm{kg}^{-1}\right)$ & $488 \pm 76$ & $508 \pm 75$ & $513 \pm 41$ & n.s. \\
\hline Total C $\left(\mathrm{g} \mathrm{kg}^{-1}\right)$ & $55.7 \pm 22.4$ & $56.7 \pm 28.6$ & $48.4 \pm 28.4$ & n.s. \\
\hline Organic $\mathrm{C}\left(\mathrm{g} \mathrm{kg}^{-1}\right)$ & $32.8 \pm 9.4 \mathrm{a}$ & $13.6 \pm 2.7 b$ & $10.9 \pm 0.6 b$ & $* * *$ \\
\hline $\mathrm{N}_{\mathrm{TOT}}\left(\mathrm{g} \mathrm{kg}^{-1}\right)$ & $3.4 \pm 0.9 \mathrm{a}$ & $3.1 \pm 0.1 \mathrm{a}$ & $1.7 \pm 0.3 \mathrm{~b}$ & $* *$ \\
\hline C:N & $16.3 \mathrm{~b}$ & $18.3 \mathrm{~b}$ & $28.4 \mathrm{a}$ & $* *$ \\
\hline POlsen (mg kg ${ }^{-1}$ ) & $164.7 \pm 45.5 \mathrm{a}$ & $27.5 \pm 13.6 \mathrm{~b}$ & $51.2 \pm 13.1 \mathrm{~b}$ & $* * *$ \\
\hline $\mathrm{S}\left(\mathrm{mg} \mathrm{kg}^{-1}\right)$ & $571 \pm 15 \mathrm{a}$ & $299 \pm 35 c$ & $438 \pm 12 b$ & $* *$ \\
\hline $\mathrm{Ca}_{\text {DTPA }}\left(\mathrm{mg} \mathrm{kg}^{-1}\right)$ & $21.81 \pm 2.6 \mathrm{a}$ & $5.63 \pm 0.3 b$ & $1.53 \pm 0.4 c$ & $* * *$ \\
\hline $\operatorname{Mg}_{\text {DTPA }}\left(\mathrm{mg} \mathrm{kg}^{-1}\right)$ & $1.11 \pm 0.22 \mathrm{a}$ & $0.90 \pm 0.1 b$ & $0.16 \pm 0.04 b$ & $* * *$ \\
\hline $\mathrm{K}_{\mathrm{DTPA}}\left(\mathrm{mg} \mathrm{kg}^{-1}\right)$ & $1.92 \pm 0.05 \mathrm{a}$ & $0.56 \pm 0.2 \mathrm{~b}$ & $0.48 \pm 0.08 \mathrm{~b}$ & $* * *$ \\
\hline $\mathrm{Na}_{\text {DTPA }}\left(\mathrm{mg} \mathrm{kg}^{-1}\right)$ & $0.45 \pm 0.05 \mathrm{a}$ & $0.27 \pm 0.06 \mathrm{~b}$ & $0.21 \pm 0.03 b$ & $* * *$ \\
\hline $\mathrm{Fe}_{\text {DTPA }}\left(\mathrm{mg} \mathrm{kg}^{-1}\right)$ & $22.7 \pm 0.6 \mathrm{a}$ & $10.7 \pm 2.2 \mathrm{~b}$ & $10.6 \pm 2.5 b$ & $* * *$ \\
\hline $\operatorname{Mn}_{\text {DTPA }}\left(\mathrm{mg} \mathrm{kg}^{-1}\right)$ & $10.5 \pm 3.0 \mathrm{a}$ & $5.0 \pm 0.9 \mathrm{~b}$ & $4.1 \pm 2.6 \mathrm{a}$ & $* *$ \\
\hline $\mathrm{Cu}_{\text {DTPA }}\left(\mathrm{mg} \mathrm{kg}^{-1}\right)$ & $36.4 \pm 14.6 \mathrm{a}$ & $4.6 \pm 1.5 \mathrm{c}$ & $2.7 \pm 0.5 b$ & $* *$ \\
\hline $\mathrm{Zn}_{\mathrm{DTPA}}\left(\mathrm{mg} \mathrm{kg}^{-1}\right)$ & $11.0 \pm 1.4 \mathrm{a}$ & $6.1 \pm 0.8 \mathrm{~b}$ & $2.1 \pm 0.5 b$ & $*$ \\
\hline $\mathrm{B}_{\text {DTPA }}\left(\mathrm{mg} \mathrm{kg}^{-1}\right)$ & $2.9 \pm 0.5 \mathrm{a}$ & $1.2 \pm 0.5 \mathrm{~b}$ & $0.7 \pm 0.2 \mathrm{~b}$ & $* * *$ \\
\hline $\mathrm{Ni}_{\text {DTPA }}\left(\mathrm{mg} \mathrm{kg}^{-1}\right)$ & $0.4 \pm 0.1$ & $0.3 \pm 0.1$ & $0.6 \pm 0.2$ & n.s. \\
\hline $\mathrm{Pb}_{\text {DTPA }}\left(\mathrm{mg} \mathrm{kg}^{-1}\right)$ & $2.8 \pm 0.4 b$ & $2.9 \pm 1.4 \mathrm{~b}$ & $1.2 \pm 0.8 \mathrm{a}$ & $* * *$ \\
\hline $\mathrm{Co}_{\text {DTPA }}\left(\mathrm{mg} \mathrm{kg}^{-1}\right)$ & $<0.1$ & $<0.1$ & $<0.1$ & \\
\hline $\mathrm{Cr}_{\text {DTPA }}\left(\mathrm{mg} \mathrm{kg}^{-1}\right)$ & $<0.1$ & $<0.1$ & $<0.1$ & \\
\hline
\end{tabular}

n.s. $=$ non significant; ${ }^{*},{ }^{* *},{ }^{* *}=$ significant at $p \leq 0.05,0.01$, and 0.001, respectively. Different letters for the same parameter indicate significant differences according to Student-Newman-Keul's test $(p=0.05)$.

In terms of controls, as concerns the possibility of soil analyses at time zero, we opted for a different choice. Indeed, as several examples of reports assessing either soil chemistry or microbial ecology aspects have demonstrated, there is a conceptual built-in bias in comparing two situations under both "across-time" + "across-treatment" variables. The reason is due to the fact that time itself brings about per se several changes even in the same soil, irrespective of its treated or untreated condition. This is due to inner consumption of organic matter and carbon emissions, anthropogenic fall-out deposition of nitrogen, sulfur and several other mineral elements, airborne microbial cell and spore immigration with daily discharge ruled by meteorological events. These could also irregularly include dust particles from other continents as often seen by Saharan trans-Mediterranean wind outbreaks. As a consequence, when analyzing the same site over time, if it also received farm-scale agricultural treatments, it would not be possible to decouple the net effect due to local practices and concomitant global changes in the chemistry and biology of the area. For this reason, to avoid such double-variable confounding effect, the choice was to rely on the comparison of treated vs. untreated plots sampled at the same single time elapsed from the onset of the treatment. As regards the control soil, being located adjacent to the treated ones and sharing the same geology as bedrock substrate (carbonate plateau), the same pedological classification, and the same climate and indirect atmospheric inputs, it is regarded as isogenic to the treated plots and differis only for the management practices, which are the rationale and object of this report.

\subsection{Compost Analyses}

Compost analyses were performed as previously described [22]. Briefly, dry weight was determined from $100 \mathrm{~g}$ of wet sample by leaving the samples at $40{ }^{\circ} \mathrm{C}$ for $24 \mathrm{~h}$ and 
then at $105^{\circ} \mathrm{C}$ for $24 \mathrm{~h}$ (APHA 1992). Carbon, $\mathrm{N}$, and $\mathrm{S}$ content were measured using a CNS automatic analyzer (Vario Macro CNS, Elementar, Hanau, Germany). Organic-N was calculated by subtracting $\mathrm{NH}_{4}{ }^{+}$determined by selective electrode from total Kjeldahl $\mathrm{N}$ [23]. Macro- and micronutrients and heavy metals were quantified by inductively coupled plasma optical emission spectrometry (ICP-OES) (Spectro Analytical Instruments $\mathrm{GmbH}$, Kleve, Germany) preceded by acid digestion, while the hexavalent chromium (Cr VI+) was determined spectrophotometrically [24]. Additional analyses, such as pH, electrical conductivity (EC), and humic carbon (HC) were performed in accordance with the compost analytical method [24], as required by the Italian legislation. For germination index (GI), a Lepidium sativum L. test was performed on a water extract of a fresh sample of mature compost (1:10 w/v for $1 \mathrm{~h}$ ). Five $\mathrm{mL}$ of the extract was pipetted into a petri dish lined with a Whatman filter paper where 10 seeds were placed for an incubation period of $48 \mathrm{~h}$ at $25^{\circ} \mathrm{C}$ in the dark. GI was calculated according to Zucconi et al. [25]. All analyses were performed in triplicate.

\subsection{Soil Sampling and Analyses}

Soil samples were collected in March 2018. In each agroecosystem, ten samples were taken with an auger from a 0 to $20 \mathrm{~cm}$ depth. Sub-samples (five) were bulked to obtain a sample of about $1 \mathrm{~kg}$ per agroecosystem. The samples were air dried, crushed by a rolling pin to break up clods, passed through a $2 \mathrm{~mm}$ sieve, and stored at room temperature.

Soil $\mathrm{pH}$ was potentiometrically measured on 1:2.5 soil/water extracts. Carbon, N, and $\mathrm{S}$ content were determined by dry combustion in a CNS analyzer (Vario Macro CNS, Elementar, Hanau, Germany). Organic C was determined by CNS analyzer and corrected by the inorganic C. Particle size analysis was performed according to the hydrometer method using sodium hexametaphosphate as a dispersant [26]. Available P was obtained by shaking $1.0 \mathrm{~g}$ of soil with $20 \mathrm{~mL}$ of $0.5 \mathrm{~mol} \mathrm{~L}^{-1}$ sodium bicarbonate solution ( $\mathrm{pH} 8.5$ ) for 30 min [27]. The extract was filtered through Whatman No. 42 filter paper, and the P was determined by ICP-OES spectrometry (Spectro Analytical Instruments GmbH, Kleve, Germany). Metals were extracted by an acid mixture, conversely for the forms available to the plant, Mehlich3 (M) [28] and diethylenetriaminepentaacetic acid (DTPA) solutions [29] were used. All metals of the extracts were analyzed by ICP-OES spectrometry. All analyses were performed in triplicate.

\subsection{Bacterial Community Analysis by $16 S$ DNA Sequences Metabarcoding}

Triplicate samples of $1 \mathrm{~g}$ of Organic Forest compost were used. Genomic DNA was extracted using the PowerSoil ${ }^{\circledR}$ DNA Isolation Kit (MO BIO laboratories Inc., Carlsbad, CA, USA) according to the manufacturer's instructions. The quantity and quality assessment of the extracted DNA were performed using NanoDrop (ThermoFisher Scientific, Waltham, MA, USA) and Qubit Fluorometer (ThermoFisher Scientific, Waltham, MA, USA), respectively. Library preparation was performed on the V4 region of 16S rRNA gene using universal primers (i.e., 515f/806r). Sequencing was performed using an Illumina MiSeq platform. The raw sequencing data were processed using a CLC Workbench software (V.8.0.2) with Microbial genomics module plug in (QIAGEN Bioinformatics, Hilden, Germany). The procedure followed was detailed previously [30]. The BLASTn against the $16 S$ ribosomal RNA (bacteria and archaea) database was used to assist and/or verify the taxonomical assignment obtained by the CLC annotation (Greengenes v13_5 database).

\subsection{Statistics}

The data collected were tested for normality and homoscedasticity by Shapiro-Wilk's and Levene's tests, respectively. One-way analysis of variance (ANOVA) was used for the comparisons between organic and conventional managed soils for all physical and chemical variables, both for vineyards and field-scale soils separately as for the spoon gardens and wooded soils. Means were separated by the Student-Newman-Keuls test at a $5 \%$ level of significance $(p \leq 0.05)$. The relationship between variables was tested by 
Pearson correlation coefficients. To identify the structure of the interdependences between the main soil parameters, a joint principal components analysis (PCA) was performed on the following variables: $\mathrm{pH}, \mathrm{EC}$, salinity, sand, clay, OC, $\mathrm{N}_{\mathrm{TOT}}, \mathrm{S}$, POlsen, CaTOT, and DTPA metals (i.e., $\mathrm{Ca}_{\mathrm{DTPA}}, \mathrm{Mg}_{\mathrm{DTPA}}, \mathrm{Na}_{\mathrm{DTPA}}, \mathrm{K}_{\mathrm{DTPA}}, \mathrm{Al}_{\mathrm{DTPA}}, \mathrm{Fe}_{\mathrm{DTPA}}, \mathrm{B}_{\mathrm{DTPA}}, \mathrm{Mn}_{\mathrm{DTPA}}, \mathrm{Zn}_{\mathrm{DTPA}}$, $\mathrm{Cu}_{\text {DTPA }}, \mathrm{Mo}_{\text {DTPA }}, \mathrm{Ni}_{\text {DTPA }}$, and $\left.\mathrm{Pb}_{\text {DTPA }}\right)$. The standardized variables were submitted to PCA; rotated orthogonal components (varimax method of rotation) were extracted, and the relative scores were determined. Only PCs with eigenvalue $>1$ were considered for the discussion. In addition, cluster analysis was applied to identify structures within the data by identifying homogenous groups of cases. Statistics were carried out using SPSS for Windows software, version 26.0 (IBM SPSS, Chicago, IL, USA).

\section{Results and Discussion}

\subsection{Compost Physical, Chemical, and Biological Characteristics}

The physical, chemical, and biological characteristics of the wood-based compost (WBC) are shown in Table 1.

The EC and main nutrients indicated values within the range usually found for green compost $[13,15,31,32]$. In particular, the total $\mathrm{N}\left(31 \mathrm{~g} \mathrm{~kg}^{-1}\right), \mathrm{K}\left(13,000 \mathrm{mg} \mathrm{kg}^{-1}\right)$, $\mathrm{S}\left(4600 \mathrm{mg} \mathrm{kg}^{-1}\right)$, and $\mathrm{Ca}\left(26,700 \mathrm{mg} \mathrm{kg}^{-1}\right)$ content values were similar to those reported for green and pruning wastes compost [31], whereas the content in P (3100 mg kg${ }^{1}$ ) resembled the value observed in a compost produced from urban green waste [32]. The content in Fe $\left(13,371 \mathrm{mg} \mathrm{kg}^{-1}\right)$ was similar to the range reported for other organic amendments [33]. The C:N ratio was of 11.09 and was largely within the recommended values. This parameter is usually used to assess the maturity of the compost.

Thus, a ratio between 10 and 15 is considered to be typical of stable composts [34], although the final ratio depends significantly on the initial material used. In line with this finding, the high humic-like $C$ content (i.e., 7-fold that requested) and the HA:FA ratio (6.5) well support the maturity of WBC [35]. Several studies have shown a significant increase in HA:FA ratio during composting, and values between 3 and 7.5 are considered typical of a mature compost [36].

Potentially toxic elements, such as $\mathrm{Cd}, \mathrm{Cr}, \mathrm{Ni}, \mathrm{Pb}$, and $\mathrm{Co}$, did not exceed the limits permitted by Italian law.

No pathogens such as Salmonella sp. or Escherichia coli were found. Mature compost is expected to be characterized by the absence of substances inhibiting seed germination. Values of the germination index (GI) equal to or lower than $50 \%$ are indicative of phytotoxicity [25], whereas a GI over $80 \%$ denotes the absence of phytotoxicity and ability to support biological activity [37]. The compost phytotoxicity test gave a GI value of 130\%, thus being >100 might improve plant early stages of growth. This value is also in the range found in other green composts [22,31].

\subsection{Bacterial Community Composition of the Compost}

A total of 221,974 filtered high-quality sequences were obtained accounting for 5462 different taxa (operational taxonomic units clustered at $>97 \%$ shared similarity). The distribution among the three replicates was the following: Replicate \#1: 86,179 sequences with 3138 taxa; Replicate \#2: 63,468 sequences with 2985 taxa; Replicate \#3 72,317 sequences with 2920 taxa. The replicates' results were very coherent and agreed with the scores of the following top taxa. The most abundant was the order Acidimicrobiales, which averaged $3.78 \%$ of the reads. It is a group from the Actinomicetes phylum that characterizes hot, acidic habitats, rich in reduced forms of sulfur and capable of oxidizing iron [38].

The second most abundant taxon $(2.69 \%)$ was the Caldilineacee family within the Anaerolineaceae class. These are thermophilic methanogenic bacteria, often observed in submerged sediments or wastewater treatment bioreactors [39]. Third in the rank (2.38\%) was the family Cytophagaceae, which are heterotrophic bacteria, strong degraders of cellulose and other complex organic polymers [40]; the following most abundant group (1.99\%) was the Archaeon genus Nitrososphaera, which encompasses typical members of the nitri- 
fication pathways, oxidizing ammonium to nitrite [41]. The next in score was the family Saprospiraceae, thriving in environments of activated sludge and representing degraders of complex organic substances, whose presence, coupled with that of Nitrososphaera, has been reported as typical of conditions leading to incomplete nitrification [42]. Overall, the compost appears endowed with a consistent biodiversity, and its features are rather individual in comparison to other compost cases. It appears more related to composts from winemaking pruning byproducts [22] and very different from those derived by vermicomposting of urban wastes [43].

\subsection{Soil Fertility, Macro and Micronutrients in Organically and Conventionally Managed Soils}

One-way ANOVA on agroecosystem data was performed to evaluate the influence of organic vs. conventional fertilization on soil properties. Post hoc analyses were performed on the most significant parameters.

The addition of WBC in vineyards and field crops considerably affected some important soil parameters compared to those of conventional and untreated soils (Tables 2 and 3). Organic V and OFS led a slight alkalinization (8.0) with respect to untreated soils (7.7). Electrical conductivity (EC) was greater in organic treated than in conventional treated soils $(p \leq 0.05)$. Indeed, the EC decreased from 1.5 to $1.1\left(\mathrm{mS} \mathrm{cm}^{-1}\right)$ in OFS and CFS, respectively, and it decreased from 0.6 to $0.4\left(\mathrm{mS} \mathrm{cm}^{-1}\right)$ in $\mathrm{OV}$ and $\mathrm{CV}$. Despite this, the most important benefit of the addition of WBC was the impressive increase in the organic C (OC) content. In fact, OC rose to $32.8 \mathrm{~g} \mathrm{~kg}^{-1}$ in OV and $35.1 \mathrm{~g} \mathrm{~kg}^{-1}$ in OFS, with respect to the value of ca $14 \mathrm{~g} \mathrm{~kg}^{-1}$ in the conventional trials $(p \leq 0.05)$. This corresponds to up to a 2.5 -fold value when compared to the conventional agroecosystems. Soil organic carbon content was improved after adding a single compost dose $\left(60 \mathrm{t} \mathrm{ha}^{-1}\right)$ for a short period (3 years). Other studies conducted in soils treated with a mixture of compost, municipal solid waste, and wood residue over a short period of time ( 2 years) also supported this result. Through this treatment, an increase in soil organic matter was observed at approximately $55 \%$ and $60 \%$ [44]. This may be a good starting point for increasing the soil organic carbon content over time [5,45]: an issue of relevance in poorly fertile agricultural soils.

In addition, also significant was the decrease in the $\mathrm{C}: \mathrm{N}$ ratio as a consequence of the amendment with WBC. Indeed, both OFS and OV had lower C:N ratio values (17.4 and 16.3, respectively) than CFS and CV (19.4 and 18.2, respectively) ( $p \leq 0.05)$. The C:N ratio is seen as an important predictor of the mineralization rate of organic $C$ and nutrient release [46]. The most important mechanism is due to the behaviour of soil microorganisms demanding quantities of organic $\mathrm{C}$ and $\mathrm{N}$ essential for growth. For this reason, a key step in managing soil quality, in a sustainable manner, is to ensure a satisfactory balance between organic $\mathrm{C}$ stock recovery and nutrient mineralization. In addition, the soil characteristics also have to be considered. In general, the amount of organic $C$ by the compost that is held in soils is influenced by its chemical properties, but also by its interactions with clay fractions, as well as carbonate and organic C content [47]. High clay content has the potential to stabilize exogenous organic matter as it is better absorbed and less susceptible to microbial attack. On the other hand, in sandy soil, mineral particles have a minor capacity to interact with organic compounds, and therefore allow a higher availability of the same microbial degradation [14].

Alkaline soils are often characterized by low solubility of P; consequently, plants that do not receive mineral fertilizers have a serious $P$ deficiency [48]. In our study, organic fertilization increased the amount of available $\mathrm{P}$, showing the highest POlsen value in OV, which was 6 times more than CV. Delgado et al. [49] showed that increasing the content of humic substances led to an augmentation and recovery of POlsen in all monitored soils, except in those with high levels of Na. Humic substances can create strong interactions with $\mathrm{P}$ via cationic metals that act as a bridge between humic substances and anionic phosphates [50]. Stability constants in P-cation complexes tend to be high and therefore stable. This result is in line with the increase in the available $\mathrm{P}$ and decrease in P-insolubilization followed with the addition of farmyard manure to calcareous soils [51]. Regarding sulphur, 
slight increments were observed with WBC amendment likely accounting for relevant benefits on the part of humic-like components to crop nutritional quality as recently seen with humic substances [52].

Table 3. Physical and chemical characteristics of the soil top layer of the field-scale amended with the wood-based compost (OFS), conventionally fertilized (CFS), and untreated (UNT) soil. Values represent the average of 10 replicates (main \pm and standard deviation).

\begin{tabular}{|c|c|c|c|c|}
\hline \multirow{2}{*}{ Parameter } & \multicolumn{2}{|c|}{ Field-Scale } & \multirow{2}{*}{ Untreated } & \multirow{2}{*}{ Anova } \\
\hline & Organic & Conventional & & \\
\hline $\mathrm{pH}$ & $8.0 \pm 0.1$ & $7.7 \pm 0.1$ & $7.7 \pm 0.2$ & n.s. \\
\hline $\mathrm{EC}\left(\mathrm{mS} \mathrm{cm}^{-1}\right)$ & $1.5 \pm 0.2 \mathrm{a}$ & $1.1 \pm 0.1 \mathrm{~b}$ & $0.2 \pm 0.1 \mathrm{c}$ & $*$ \\
\hline Sand $\left(\mathrm{g} \mathrm{kg}^{-1}\right)$ & $360 \pm 69$ & $350 \pm 67$ & $280 \pm 52$ & n.s. \\
\hline Silt $\left(\mathrm{g} \mathrm{kg}^{-1}\right)$ & $176 \pm 32$ & $200 \pm 28$ & $206 \pm 11$ & n.s. \\
\hline Clay $\left(\mathrm{g} \mathrm{kg}^{-1}\right)$ & $464 \pm 51$ & $450 \pm 42$ & $513 \pm 41$ & n.s. \\
\hline Total $C\left(\mathrm{~g} \mathrm{~kg}^{-1}\right)$ & $54.0 \pm 19.6$ & $66.2 \pm 3.2$ & $48.4 \pm 28.4$ & n.s. \\
\hline Organic $C\left(\mathrm{~g} \mathrm{~kg}^{-1}\right)$ & $35.1 \pm 2.3 \mathrm{a}$ & $14.0 \pm 0.6 \mathrm{~b}$ & $10.9 \pm 0.6 c$ & $* * *$ \\
\hline $\mathrm{N}_{\text {TОт }}\left(\mathrm{g} \mathrm{kg}^{-1}\right)$ & $3.1 \pm 0.5$ & $3.4 \pm 0.1$ & $1.7 \pm 0.3$ & $* *$ \\
\hline C:N & $17.4 b$ & $19.4 b$ & $28.4 a$ & * \\
\hline POlsen $\left(\mathrm{mg} \mathrm{kg}^{-1}\right)$ & $121.6 \pm 9.8 \mathrm{a}$ & $62.7 \pm 13.4 b$ & $51.2 \pm 13.1 b$ & $* * *$ \\
\hline $\mathrm{S}\left(\mathrm{mg} \mathrm{kg}^{-1}\right)$ & $560 \pm 16 a$ & $418 \pm 22 b$ & $438 \pm 22 b$ & $* *$ \\
\hline $\mathrm{Ca}_{\text {DTPA }}\left(\mathrm{mg} \mathrm{kg}^{-1}\right)$ & $18.51 \pm 2.11 \mathrm{a}$ & $10.14 \pm 0.6 \mathrm{~b}$ & $1.53 \pm 0.4 \mathrm{c}$ & $* *$ \\
\hline $\operatorname{Mg}_{\text {DTPA }}\left(\mathrm{mg} \mathrm{kg}^{-1}\right)$ & $0.86 \pm 0.15 \mathrm{a}$ & $0.19 \pm 0.15 b$ & $0.16 \pm 0.04 b$ & $* *$ \\
\hline $\mathrm{K}_{\text {DTPA }}\left(\mathrm{mg} \mathrm{kg}^{-1}\right)$ & $0.82 \pm 0.12 \mathrm{a}$ & $0.25 \pm 0.04 c$ & $0.48 \pm 0.08 \mathrm{~b}$ & $* * *$ \\
\hline $\mathrm{Na}_{\text {DTPA }}\left(\mathrm{mg} \mathrm{kg}^{-1}\right)$ & $0.63 \pm 0.14 \mathrm{a}$ & $0.37 \pm 0.06 b$ & $0.21 \pm 0.03 \mathrm{~b}$ & $* *$ \\
\hline $\mathrm{Fe}_{\mathrm{DTPA}}\left(\mathrm{mg} \mathrm{kg}^{-1}\right)$ & $22.5 \pm 0.5 \mathrm{a}$ & $7.5 \pm 1.5 c$ & $10.6 \pm 2.5 \mathrm{~b}$ & $* * *$ \\
\hline $\operatorname{Mn}_{\text {DTPA }}\left(\mathrm{mg} \mathrm{kg}^{-1}\right)$ & $19.8 \pm 1.6 \mathrm{a}$ & $5.5 \pm 4.4 \mathrm{~b}$ & $4.1 \pm 2.6 \mathrm{~b}$ & $* *$ \\
\hline $\mathrm{Cu}_{\text {DTPA }}\left(\mathrm{mg} \mathrm{kg}^{-1}\right)$ & $15.5 \pm 1.6 \mathrm{~b}$ & $5.1 \pm 1.8 \mathrm{~b}$ & $2.7 \pm 0.5 \mathrm{a}$ & $* *$ \\
\hline $\mathrm{Zn}_{\text {DTPA }}\left(\mathrm{mg} \mathrm{kg}^{-1}\right)$ & $6.9 \pm 3.0 \mathrm{a}$ & $3.7 \pm 1.2 \mathrm{~b}$ & $2.1 \pm 0.5 \mathrm{a}$ & $* *$ \\
\hline $\mathrm{B}_{\text {DTPA }}\left(\mathrm{mg} \mathrm{kg}^{-1}\right)$ & $3.4 \pm 0.6 \mathrm{a}$ & $2 \pm 0.8 \mathrm{a}$ & $0.7 \pm 0.2 \mathrm{~b}$ & $* *$ \\
\hline $\mathrm{Ni}_{\text {DTPA }}\left(\mathrm{mg} \mathrm{kg}^{-1}\right)$ & $1.2 \pm 0.5$ & $1.1 \pm 0.5$ & $0.6 \pm 0.2$ & n.s. \\
\hline $\mathrm{Pb}_{\text {DTPA }}\left(\mathrm{mg} \mathrm{kg}^{-1}\right)$ & $3.6 \pm 0.8 \mathrm{~b}$ & $6.4 \pm 0.6 \mathrm{a}$ & $1.2 \pm 0.8 \mathrm{a}$ & $*$ \\
\hline Co DTPA $\left(\mathrm{mg} \mathrm{kg}^{-1}\right)$ & $<0.1$ & $<0.1$ & $<0.1$ & \\
\hline $\mathrm{Cr}_{\text {DTPA }}\left(\mathrm{mg} \mathrm{kg}^{-1}\right)$ & $<0.1$ & $<0.1$ & $<0.1$ & \\
\hline
\end{tabular}

The content in plant available macro- (Ca, $\mathrm{Mg}$, and K-DTPA extracted) and micronutrients ( $\mathrm{Na}, \mathrm{Fe}, \mathrm{Mn}, \mathrm{Cu}, \mathrm{Zn}$-DTPA extracted) in vineyards and field-scale crops showed a considerable variation depending on fertilization treatment, with values generally higher when soils were treated with organic than with conventional fertilization (Tables 2 and 3).

The most affected nutrient was Ca: Ca DTPA increased by 14-fold in OV as compared to $\mathrm{CV}$. Moreover, OV exhibited a 6.9-fold value in $\mathrm{Mg}_{\text {DTPA }}$ and 4-fold values in $\mathrm{K}_{\mathrm{DTPA}}$, with respect conventional fertilization, while OFS reported 5.3-fold values in $\mathrm{Mg}_{\mathrm{DTPA}}$ and 1.7 -fold values in $\mathrm{K}_{\mathrm{DTPA}}$, with respect conventional treatment. WBC highly increased the content in $\mathrm{Cu}_{\mathrm{DTPA}}$ in vineyard, giving values 7.9-fold of those in conventional management. The increases in $\mathrm{Cu}$ availability appear to be likely due to the high quantity of organic $\mathrm{C}$ and phytosanitary treatments $[53,54]$. Organic management also increased the content in Fe $\mathrm{D}_{\mathrm{DTPA}}, \mathrm{Mn}_{\mathrm{DTPA}}, \mathrm{Zn}_{\mathrm{DTPA}}$, and $\mathrm{B}_{\mathrm{DTPA}}$ with values ranging from 1.8-3.6-fold those of conventional fertilization. These data are in line with previous studies that reported that the compost addition determined in the soil an extra nutrient budget [15].

Contrary to the DTPA extractable metals, the Mehlich3 extractables metals and the total metals contents were not affected by fertilization (data not shown). Mehlich3 metals and total metals content both come from strong hydrolyses and were related to each other. Indeed, among the mostly significant correlations, $\mathrm{Al}_{\mathrm{M}}, \mathrm{Cu}_{\mathrm{M}}$, and $\mathrm{Mg}_{\mathrm{M}}$ resulted in being greatly correlated with their total content $(r=0.89,0.87,0.76$, respectively; $p \leq 0.01)$ (Table S1, Supplementary Material). 
This result may indicate that metal total concentration is more closely related to the geochemical composition of the parent material [55]. Nevertheless, the $\mathrm{Cr}, \mathrm{Cu}, \mathrm{Ni}, \mathrm{Pb}$, and Zn total concentrations were lower than the Italian legal thresholds, therefore excluding any environmental risk. To note, instead, most of the macro and micronutrients contents were significantly correlated with the organic $C$. The strongest positive correlation coefficients between organic $\mathrm{C}$ were demonstrated with respect to the content of $\mathrm{B}_{\mathrm{DTPA}}(\mathrm{r}=0.88$, $p \leq 0.001), \operatorname{Mg}_{\text {DTPA }}(\mathrm{r}=0.86, p \leq 0.001)$, POlsen $(\mathrm{r}=0.81, p \leq 0.001), \mathrm{S}(\mathrm{r}=0.76, p \leq 0.001)$, $\mathrm{Zn}_{\mathrm{M}}(\mathrm{r}=0.76, p \leq 0.001)$, and $\mathrm{Fe} \mathrm{M}(\mathrm{r}=0.75, p \leq 0.001)$. A slightly weaker correlation was found with $\mathrm{Pb}_{\mathrm{DTPA}}(\mathrm{r}=-0.50, p \leq 0.001)$ and $\mathrm{Mo}_{\mathrm{M}}(\mathrm{r}=-0.45, p \leq 0.005)$. Concerning other relationships, $\mathrm{P}_{\mathrm{M}}$ showed a high correlation with POlsen $(\mathrm{r}=0.92, p \leq 0.001)$, whereas

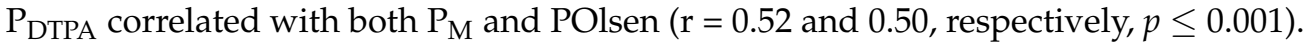

\subsection{Principal Component Analysis and Cluster Analysis}

Principal component analysis was performed to obtain a smaller number of linear combinations of all considered variables, which were significantly representative of the experimental results. Three main components were extracted that had eigenvalues greater than 1.0. Together they accounted for $79 \%$ of the variability in the original data (Table 4).

Table 4. Eigenvalues, variance explained, and loading values of the selected physical and chemical variables on the axes identified by principal components analysis for the differently managed soils.

\begin{tabular}{|c|c|c|c|}
\hline Principal Components & PC1 & PC2 & PC3 \\
\hline Eigenvalue & 9.2 & 3.7 & 2.9 \\
\hline Variance (\%) & 46 & 18 & 15 \\
\hline Cumulative variance (\%) & 46 & 64 & 79 \\
\hline \multicolumn{4}{|l|}{ Eigenvectors } \\
\hline CaDTPA & 0.97 & 0.01 & 0.17 \\
\hline $\mathrm{B}_{\mathrm{DTPA}}$ & 0.96 & -0.12 & 0.08 \\
\hline $\mathrm{OC}$ & 0.96 & 0.06 & 0.15 \\
\hline $\mathrm{Mg}_{\text {DTPA }}$ & 0.95 & 0.06 & 0.23 \\
\hline $\mathrm{Fe}_{\mathrm{DTPA}}$ & -0.95 & -0.04 & -0.05 \\
\hline POlsen & 0.92 & 0.19 & 0.17 \\
\hline $\mathrm{Na}_{\text {DTPA }}$ & 0.89 & 0.14 & -0.05 \\
\hline $\mathrm{K}_{\mathrm{DTPA}}$ & 0.88 & -0.10 & 0.18 \\
\hline Mo DTPA & -0.82 & 0.44 & -0.07 \\
\hline EC & -0.73 & 0.24 & 0.38 \\
\hline $\mathrm{Pb}_{\text {DTPA }}$ & -0.69 & 0.19 & 0.57 \\
\hline $\mathrm{Zn}_{\text {DTPA }}$ & 0.63 & 0.38 & 0.23 \\
\hline $\mathrm{CT}$ & -0.03 & 0.80 & -0.26 \\
\hline Sand & 0.22 & 0.80 & -0.29 \\
\hline Clay & -0.10 & -0.79 & 0.30 \\
\hline $\mathrm{N}_{\mathrm{TOT}}$ & -0.06 & 0.75 & 0.34 \\
\hline $\mathrm{Mn}_{\text {DTPA }}$ & -0.36 & 0.68 & 0.01 \\
\hline $\mathrm{Ni}_{\text {DTPA }}$ & 0.26 & 0.51 & 0.45 \\
\hline $\mathrm{Cu}_{\text {DTPA }}$ & -0.11 & 0.03 & 0.79 \\
\hline $\mathrm{pH}$ & 0.48 & 0.18 & -0.74 \\
\hline
\end{tabular}

The first and second components of the PCA accounted for $46 \%$ and $18 \%$, respectively, of the total variation of the traits investigated. The remaining $15 \%$ of the total variance was explained by the third component of the PCA. The eigenvectors satisfactorily characterized the different treatments, which were grouped into the main sectors of the score plot. Plotting data according to PC1 and PC2 (Figure 1A) allowed two clusters to be identified corresponding to cases OV and OFS on the right side and UNT, CV, and CFS on the left side. It resulted in well-separated soils of organic fertilization from soils of conventional fertilization along the first principal component. It should be noted (Figure 1B) that $\mathrm{Ca}_{\mathrm{DTPA}}$, OC, $\mathrm{B}_{\mathrm{DTPA}}, \mathrm{Mg}_{\mathrm{DTPA}}, \mathrm{POl}$ sen, and $\mathrm{K}_{\mathrm{DTPA}}$ were strongly and positively correlated with the

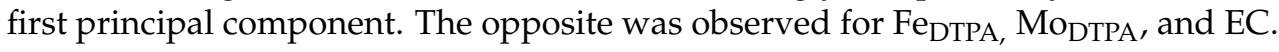



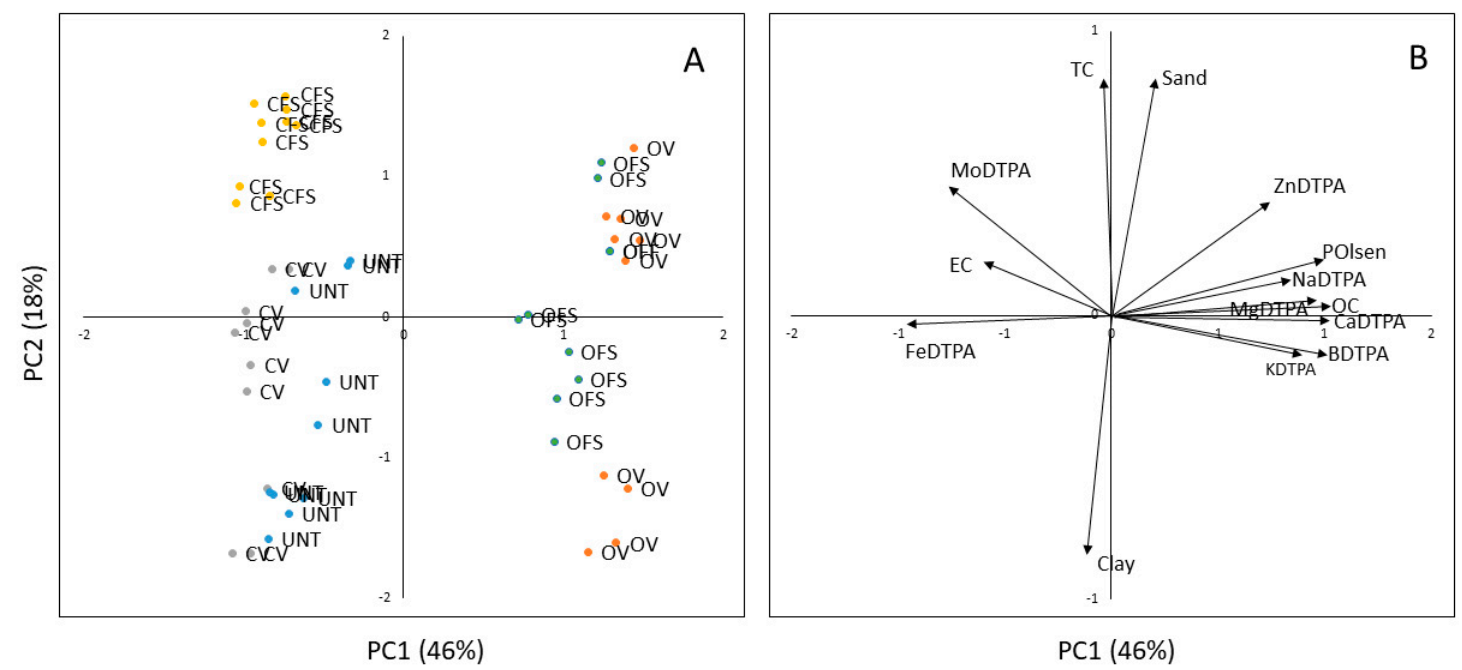

Figure 1. Positions of soil samples (OV, organic vineyard; OFS, organic field-scale; CV, conventional vineyard; CFS, conventional field-scale; UNT, untreated = control) in the reduced space of the first two principal components after principal components analysis (A). Variables projected in the plane determined by the first two principal components (B): Ca $a_{D T P A}$ calcium DTPA extractable; $\mathrm{B}_{\mathrm{DTPA}}$, borum DTPA extractable; OC, organic carbon; $\mathrm{Mg}_{\mathrm{DTPA}}$, magnesium DTPA extractable; $\mathrm{Fe}_{\mathrm{DTPA}}$, iron DTPA extractable; POlsen, phosphorus Olsen extractable; Na $a_{\mathrm{DTPA}}$, sodium DTPA extractable; $\mathrm{K}_{\mathrm{DTPA}}$, potassium DTPA extractable; Mo DTPA, molibdenum DTPA extractable; EC, electrical conductivity; Pb $\mathrm{DTPA}_{\mathrm{DT}}$, lead DTPA extractable; $\mathrm{Zn}_{\text {DTPA }}$, zinc DTPA extractable; $\mathrm{CT}$, total carbon; $\mathrm{N}_{\mathrm{TOT}}$, total nitrogen; $\mathrm{Mn}_{\mathrm{DTPA}}$, manganese DTPA extractable; $\mathrm{Ni}_{\mathrm{DTPA}}$, nickel DTPA extractable; $\mathrm{Cu}_{\mathrm{DTPA}}$, cuprum DTPA extractable:.

Cluster analysis on the data sets included the basic soil properties and DTPA metals content, which resulted in a significant distinction between fertilization management, and within the same management it distinguished cases by agroecosystem. Otherwise, the cases resulted somewhat mixed between them when data sets included metals extracted with Mehlich3 solution and total metal content (data not shown). Basic soil properties and DTPA metals content defined two pair of boxes corresponding to organic vs. conventional fork (Figure 2). The interesting exception are the untreated cases which fall in the conventional cases. In the dendrogram description and moving from the organic fertilization, in the lower phenon we distinguish the organic vineyard from the organic field-scale crops. Moving to the conventional fertilization phenon, the conventional field-scale cases appear clearly separated from the other groups, whereas conventional vineyard and untreated cases were somewhat mismatched. Thus, fertilization management seems to be a determinant on basic soil properties and DTPA extractable metals, while the type of agroecosystem has a lesser effect.

DTPA extracts the fraction of elements most available to the plants, thus mimicking the action performed by root exudates in extracting the elements from the total pool $[29,56]$.

It is not surprising that the first action of an amendment is to influence this pool of available elements. It is also interesting that we have found somewhat of a relationship between the cultivated ecosystem and the pool of elements extracted by DTPA, as shown by the cluster analysis. In the past, in fact, it has been seen how root exudates are able to mobilize biostimulating fractions from the soil for the growth of plants, and how there is a strict relationship between plants and the mobilized fraction [57]. Yet, in this work the cluster analysis based on DTPA metals allows one to distinguish not only between organic and conventional treatment but also between ecosystem group. 


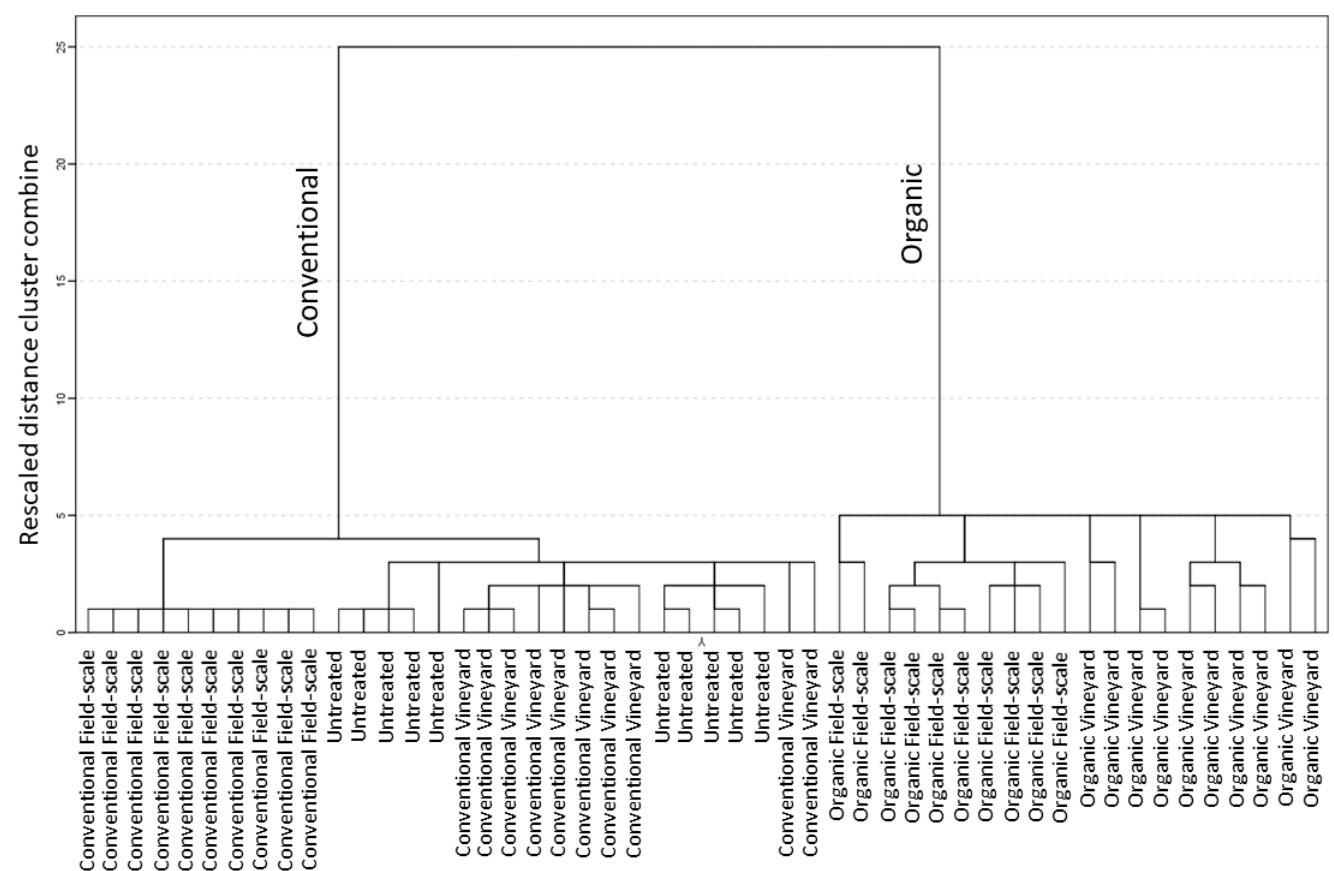

Figure 2. Dendrogram of the cluster analysis of main soil properties and DTPA extractable metals in the organic and conventional fertilized soils (vineyard, field-scale, and untreated = control).

Our study demonstrated that organically managed soils with wood-based compost addition exhibited higher levels of organic $\mathrm{C}$, macronutrients, and plant-available micronutrients content than conventionally managed soils. In contrast, the heavy metal contents did not show significant differences. The untreated soil has a slightly neutral $\mathrm{pH}$, small $\mathrm{EC}$ and organic $\mathrm{C}$ content, and a limited amount of nutrients, which indicate a low agronomical fertility. The increase in EC in organically treated soils was recorded also from different authors [15], although the relatively low EC levels in the organic system indicate that the use of wood-based compost has not resulted in increased salinity. This result agrees with those of Melero et al. [58] which did not find significant differences in salinity between conventional and organic fertilization. Fertilized soils resulted in increases in organic $\mathrm{C}, \mathrm{N}, \mathrm{P}$, and $\mathrm{S}$ which were more influenced in the organic system then in the conventional fertilization.

Treatments affected macro- and micronutrients content, also with a general decreasing value from organic to conventional fertilization to untreated soils. Plant-available metals also increased under organic fertilization with respect to the conventional one. The application of organic compost to soil affected the availability of micronutrients such as $\mathrm{Fe}$, $\mathrm{Cu}, \mathrm{Mn}$, and $\mathrm{Zn}$ with a higher plant available extractability than conventional inorganic fertilization as found previously [9,56]. Wierzbowska et al. [32] reported increased values in $\mathrm{Cu}$ and $\mathrm{Zn}$ in soil fertilized with compost from unsorted household waste and in soil treated with sewage sludge. The content of most heavy metals in soil was positively correlated with the organic carbon as found in this and other studies [32]. On the contrary, the presence of stabilized organic matter containing high molecular weight humic acids, such as the one observed in WBC, might induce permanent binding of heavy metals and their immobilization.

\section{Conclusions}

Wood-based compost showed physical and chemical characteristics that allow this product to be considered for use as an amendment in organic farming system. Indeed, the utilization of wood-based compost in organic farming is encouraged due to enhanced soil fertility consistent with higher organic $C$ and macro- and micronutrients content with respect to conventional fertilization. A higher plant-available (DTPA) extractability of 
micronutrients has also been found in soils amended with WBC. Although WBC-amended soils were examined after a single dose and after a short period, to reinforce the results obtained and to verify the effects of WBC on soil fertility and organic C accumulation, a study conducted for a longer period would be needed. These findings constitute relevant encouraging premises for the use of WBC in organic-based low-intensity agricultural management.

Supplementary Materials: The following are available online at https:/ / www.mdpi.com/2073-439 5/11/3/518/s1, Table S1: Correlations coefficient $r$ between soil properties.

Author Contributions: Conceptualization, L.B., G.C., A.S. and D.P.; methodology, D.P., L.B., G.C. and A.S.; formal analysis, D.P. and L.B.; resources, G.C.; data curation, D.P., L.B., and O.F.; writingoriginal draft preparation, D.P.; writing-review and editing, D.P., O.F. and A.S.; visualization, D.P.; supervision, S.N.; funding acquisition, G.C. All authors have read and agreed to the published version of the manuscript.

Funding: This research was funded by "Progetto di Ateneo PRAT CPDA154841/15" from the University of Padova (G.C.).

Institutional Review Board Statement: Not applicable.

Informed Consent Statement: Not applicable.

Data Availability Statement: The data presented in this study are available on request from the corresponding author.

Conflicts of Interest: The authors declare no conflict of interest in that the funders had no role in the design of the study; in the collection, analyses, or interpretation of data; in the writing of the manuscript, or in the decision to publish the results.

\section{References}

1. Wiesmeier, M.; Poeplau, C.; Sierra, C.A.; Maier, H.; Frühauf, C.; Hübner, R.; Kühnel, A.; Spörlein, P.; Geuß, U.; Hangen, E.; et al. Projected loss of soil organic carbon in temperate agricultural soils in the 21st century: Effects of climate change and carbon input trends. Sci. Rep. 2016, 6, 32525. [CrossRef]

2. İmamoglu, A.; Dengiz, O. Evaluation of soil quality index to assess the influence of soil degradation and desertification process in sub-arid terrestrial ecosystem. Rend. Lincei 2019, 30, 723-734. [CrossRef]

3. Diacono, M.; Montemurro, F. long-term effects of organic amendments on soil fertility: A review. Agron. Sustain. Dev. 2010, 30, 401-422. [CrossRef]

4. De Hita, D.; Fuentes, M.; García, A.C.; Olaetxea, M.; Baigorri, R.; Zamarreño, A.M.; Berbara, R.; Garcia-Mina, J.M. Humic substances: A valuable agronomic tool for improving crop adaptation to saline water irrigation. Water Supply 2019, 19, 1735-1740. [CrossRef]

5. Gattinger, A.; Muller, A.; Haeni, M.; Skinner, C.; Fliessbach, A.; Buchmann, N.; Mäder, P.; Stolze, M.; Smith, P.; Scialabba, N.E.H.; et al. Enhanced top soil carbon stocks under organic farming. Proc. Natl. Acad. Sci. USA 2012, 109, 18226-18231. [CrossRef]

6. Niggli, U.; Fließbach, A.; Hepperly, P.; Scialabba, P. Low Greenhouse Gas Agriculture: Mitigation and Adaptation Potential of Sustainable Farming Systems; Rev. 2; FAO: Rome, Italy, 2009.

7. El-Hage Scialabba, N.; Müller-Lindenlauf, M. Organic agriculture and climate change. Renew. Agric. Food Syst. 2010, 25, 158-169. [CrossRef]

8. Leifeld, J.; Reiser, R.; Oberholzer, H.R. Consequences of conventional versus organic farming on soil carbon: Results from a 27-year filed experiment. Agron. J. 2009, 101, 1204-1218. [CrossRef]

9. Järvan, M.; Vettik, R.; Adamson, A. Assessment of plant nutrients' dynamics in organically and conventionally managed soils by means of different extraction methods. Acta Agric. Scand. Sec. B 2016. [CrossRef]

10. Drinkwater, L.E.; Letourneau, D.K.; Workneh, F.; van Bruggen, A.H.C.; Shennan, C. Fundamental differences between conventional and organic tomato agroecosystems in California. Ecol. Appl. 1995, 5, 1098-1112. [CrossRef]

11. Werner, M.W. Soil quality characteristics during conversion to organic orchard management. Appl. Soil Ecol. 1997, 5, 151-167. [CrossRef]

12. Debiase, G.; Traversa, A.; Montemurro, F.; Mastrangelo, M.; Fiore, A.; Ventrella, G.; Brunetti, G. Minimum tillage and organic fertilization for the sustainable management of Brassica carinata A. (Braun) in the Mediterranean environment. Environ. Sci. Poll. Res. 2018, 25, 33556-33565. [CrossRef] [PubMed]

13. Beesley, L.; Dickinson, N. Carbon and trace element mobility in an urban soil amended with green waste compost. J. Soils Sed. 2010, 10, 215-222. [CrossRef] 
14. Bonanomi, G.; D'Ascoli, R.; Scotti, R.; Gaglione, S.A.; Gonzalez Caceres, M.; Sultana, S.; Scelza, R.; Rao, M.A.; Zoina, A. Soil quality recovery and crop yield enhancement by combined application of compost and wood to vegetables grown under plastic tunnels. Agric. Ecosyst. Environ. 2014, 192, 1-7. [CrossRef]

15. Massa, D.; Malorgio, F.; Lazzareschi, S.; Carmassi, G.; Prisa, D.; Burchi, G. Evaluation of two green composts for peat substitution in geranium (Pelargonium zonale L.) cultivation: Effect on plant growth, quality, nutrition, and photosynthesis. Sci. Hortic. 2018, 228, 213-221. [CrossRef]

16. Kumar, M.; Ou, Y.L.; Lin, J.G. Co-composting of green waste and food waste at low C/N ratio. Waste Manag. 2010, 30, 602-609. [CrossRef] [PubMed]

17. Brito, L.M.; Reis, M.; Mourão, I.; Coutinho, J. Use of Acacia waste compost as an alternative component for horticultural substrates. Commun. Soil Sci. Plant Anal. 2015, 46, 1814-1826. [CrossRef]

18. Mugnai, S.; Pasquini, T.; Azzarello, E.; Pandolfi, C.; Mancusa, S. Evaluation of composted green waste in ornamental containergrown plants: Effects on growth and plant water relations. Compost Sci. Util. 2007, 15, 283-287. [CrossRef]

19. Raviv, M. Composts in growing media: What's new and what's next? Acta Hortic. 2013, 982, 39-52. [CrossRef]

20. World Reference Base for Soil Resources. International Soil Classification System for Naming Soil sand Creating Legends for Soil Maps; World Soil Resources Reports No. 106, Update 2015; FAO: Rome, Italy, 2014.

21. Decreto Legislativo n. 75. In Riordino e Revisione Della Disciplina in Materia di Fertilizzanti, a Norma Dell'articolo 13 Della Legge 7 Luglio 2009, n. 88; Gazzetta Ufficiale n. 121, 26 maggio; Gazzetta Ufficiale: Rome, Italy, 2010.

22. Viel, A.; Stellin, F.; Carlot, M.; Nadal, C.; Concheri, G.; Stevanato, P.; Suqartini, A.; Corich, V.; Giacomini, A. Characteristics of compost obtained from winemaking byproducts. Waste Biomass Valorization 2018, 9, 2021-2029. [CrossRef]

23. Sweeney, R.A. Generic combustion method for determination of crude protein in feeds: Collaborative study. J. Assoc. Off. Anal. Chem. 1989, 72, 770-774. [CrossRef]

24. Metodi di Analisi del Compost. In Manuali e Linee Guida; ANPA: Roma, Italy, 2001; ISBN 88-448-0258-9.

25. Zucconi, F.; Pera, A.; Forte, M.; De Bertoldi, M. Evaluating toxicity in immature compost. Biocycle 1981, $22,54-57$.

26. Gee, G.W.; Bauder, J.W. Particle-size analysis. In Methods of Soil Analysis, Part 1. Physical and Mineralogical Methods, Agronomy Monograph, 2nd ed.; Klute, A., Ed.; American Society of Agronomy/Soil Science Society of America: Madison, WI, USA, 1986; Volume 9, pp. 383-411.

27. Olsen, S.L.; Sommers, L.E. Phosphorus. In Methods of Soil Analysis, Part 2. Chemical and Microbiological Properties, 2nd ed.; Page, A.L., Miller, R.H., Keeney, D.R., Eds.; American Society of Agronomy: Madison, WI, USA, 1982; pp. $403-427$.

28. Mehlich, A. Mehlich 3 soil test extractant: A modification of Mehlich 2 extractant. Commun. Soil Sci. Plant Anal. 1984, 15, 1409-1416. [CrossRef]

29. Lindsay, W.L.; Norvell, W.A. Development of DTPA soil test for Zn, Fe, Mn and Cu. Soil Sci. Soc. Am. J. 1978, 42, 421-442. [CrossRef]

30. Treu, L.; Kougias, P.G.; de Diego-Díaz, B.; Campanaro, S.; Bassani, I.; Fernández-Rodríguez, J.; Angelidaki, I. Two-year microbial adaptation during hydrogen-mediated biogas upgrading process in a serial reactor configuration. Bioresour. Technol. 2018, 264, 140-147. [CrossRef]

31. Morales-Corts, M.R.; Gómez-Sánchez, M.Á.; Pérez-Sánchez, R. Evaluation of green/pruning wastes compost and vermicompost, slumgum compost and their mixes as growing media for horticultural production. Sci. Hortic. 2014, 172, 155-160. [CrossRef]

32. Wierzbowska, J.; Kovačik, P.; Sienkiewicz, S.; Krzebietke, S.; Bowszys, T. Determination of heavy metals and their availability to plants in soil fertilized with different waste substances. Environ. Monit. Assess. 2018, 190, 567. [CrossRef] [PubMed]

33. Quilty, J.R.; Cattle, S.R. Use and understanding of organic amendments in Australian agriculture: A review. Soil Res. 2011, 49, 1-26. [CrossRef]

34. Azim, K.; Soudi, B.; Boukhari, S.; Perissol, C.; Roussos, S.; Thami Alami, I. Composting parameters and compost quality: A literature review. Org. Agric. 2018, 8, 141-158. [CrossRef]

35. Sæbø, A.; Ferrini, F. The use of compost in urban green areas-A review for practical application. Urban For. Urban Green. 2006, 4, 159-169. [CrossRef]

36. Huang, G.; Wu, Q.; Wong, J.; Nagar, B. Transformation of organic matter during co-composting of pig manure with sawdust. Bioresour. Technol. 2006, 97, 1834-1842. [CrossRef] [PubMed]

37. Ortega, M.C.; Moreno, M.T.; Ordovás, J.; Aguado, M.T. Behaviour of different horticultural species in phytotoxicity bioassays of bark substrates. Sci. Hortic. 1996, 66, 125-132. [CrossRef]

38. Stackebrandt, E.; Rainey, F.A.; Ward-Rainey, N.L. Proposal for a new hierarchic classification system, Actinobacteria classis nov. Int. J. Syst. Bacteriol. 1997, 47, 479-491. [CrossRef]

39. Zhang, B.; Xu, X.; Zhu, L. Structure and function of the microbial consortia of activated sludge in typical municipal wastewater treatment plants in winter. Sci. Rep. 2017, 7, 17930. [CrossRef]

40. McBride, M.J.; Liu, W.; Lu, X.; Zhu, Y.; Zhang, W. The Family Cytophagaceae. In The Prokaryotes-Other Major Lineages of Bacteria and the Archaea; Rosenberg, E., DeLong, E.F., Lory, S., Stackebrandt, E., Thompson, F., Eds.; Springer: Berlin/Heidelberg, Germany, 2014; ISBN 978-3-642-38953-5. [CrossRef]

41. Tourna, M.; Stieglmeier, M.; Spang, A.; Könneke, M.; Schintlmeister, A.; Urich, T.; Engel, M.; Schloter, M.; Wagner, M.; Richter, A.; et al. Nitrososphaera viennensis, an ammonia oxidizing archaeon from soil. Proc. Natl. Acad. Sci. USA 2011, 108, 8420-8425. [CrossRef] [PubMed] 
42. Johnston, J.; LaPara, T.; Behrens, S. Composition and dynamics of the activated sludge microbiome during seasonal nitrification failure. Sci. Rep. 2019, 9, 4565. [CrossRef] [PubMed]

43. Srivastava, V.; Squartini, A.; Masi, A.; Sarkar, A.; Singh, R.P. Metabarcoding analysis of the bacterial succession during vermicomposting of municipal solid waste employing the earthworm Eisenia fetida. Sci. Total Environ. 2021, 766, 144389. [CrossRef]

44. Scotti, R.; D’Ascoli, R.; Gonzalez Carceres, M.; Bonanomi, G.; Sultana, S.; Cozzolino, L.; Scelza, R.; Zoina, A.; Rao, M.A. Combined use of compost and wood scraps to increase carbon stock and improve soil quality in intensive farming systems. Eur. J. Soil Sci. 2015, 66, 463-475. [CrossRef]

45. Beesley, L. Respiration ( $\mathrm{CO}_{2}$ flux) from urban and peri-urban soils amended with green waste compost. Geoderma 2014, 223-225, 68-72. [CrossRef]

46. Berg, B.; McClaugherty, C. Plant Litter: Decomposition, Humus Formation and Carbon Sequestration, 2nd ed.; Springer: Berlin/Heidelberg, Germany, 2008.

47. Clough, A.; Skjemstad, J.O. Physical and chemical protection of soil organic carbon in three agricultural soils with different contents of calcium carbonate. Aust. J. Soil Res. 2000, 38, 1005-1016. [CrossRef]

48. Chien, S.H.; Prochnow, L.I.; Tu, S.; Snyder, C.S. Agronomic and environmental aspects of phosphate fertilizers varying in source and solubility: An update review. Nutr. Cycl. Agroecosyst. 2011, 89, 229-255. [CrossRef]

49. Delgado, A.; Madrid, A.; Kassem, S.; Andreu, L.; del Campillo, M.C. Phosphorus fertilizer recovery from calcareous soils amended with humic and fulvic acids. Plant Soil 2002, 245, 277-286. [CrossRef]

50. Riggle, J.; von Wandruszka, R. Binding of inorganic phosphate to dissolved metal humates. Talanta 2005, 66, 372-375. [CrossRef] [PubMed]

51. Pizzeghello, D.; Berti, A.; Nardi, S.; Morari, F. Relationship between soil test phosphorus and phosphorus release to solution in three soils after long-term mineral and manure application. Agric. Ecosyst. Environ. 2016, 233, 214-223. [CrossRef]

52. Pizzeghello, D.; Schiavon, M.; Francioso, O.; Dalla Vecchia, F.; Ertani, A.; Nardi, S. Bioactivity of size-fractionated and unfractionated humic substances from two forest soils and comparative effects on $\mathrm{N}$ and $\mathrm{S}$ metabolism, nutrition, and root anatomy of Allium sativum L. Front. Plant Sci. 2020, 11, 1203. [CrossRef]

53. Regulation EC 834/2007. Available online: https://eur-lex.europa.eu/legal-content/EN/TXT/?uri=CELEX:32007R0834 (accessed on 8 March 2021).

54. Regulation EC 889/2008. Available online: https:/ / eur-lex.europa.eu/eli/reg/2008/889/oj (accessed on 8 March 2021).

55. Micó, C.; Peris, M.; Recatalá, L.; Sánchez, J. Baseline values for heavy metals in agricultural soils in an European Mediterranean region. Sci. Total Environ. 2007, 378, 13-17. [CrossRef] [PubMed]

56. Maqueda, C.; Herencia, J.F.; Ruiz, J.C.; Hidalgo, M.F. Organic and inorganic fertilization effects on DTPA-extractable Fe, Cu, Mn and $\mathrm{Zn}$, and their concentration in the edible portion of crops. J. Agric. Sci. 2011, 149, 461-472. [CrossRef]

57. Nardi, S.; Tosoni, M.; Pizzeghello, D.; Provenzano, M.R.; Cilenti, A.; Sturaro, A.; Rella, R.; Vianello, A. Chemical characteristics and biological activity of organic substances extracted from soils by root exudates. Soil Sci. Soc. Am. J. 2005, 69, 2012-2019. [CrossRef]

58. Melero, S.; Porras, J.C.R.; Herencia, J.F.; Medejon, E. Chemical and biochemical properties in a silty loam soil under conventional and organic management. Soil Tillage Res. 2006, 90, 162-170. [CrossRef] 